\title{
A study on effective factors on employee motivation
}

\author{
Hassan Ghodrati ${ }^{\mathrm{a}}$ and Reza Ghaffari Tabar ${ }^{\mathrm{b} *}$
}

${ }^{a}$ Accounting \& Management Department, Kashan Branch, Islamic Azad University, Kashan, Iran ${ }^{b}$ Department of Management, Naragh Branch, Islamic Azad University, Naragh, Iran

\section{CH R O N I C L E}

Article history:

Received January 22, 2013

Received in revised format

26 April 2013

Accepted 20 May 2013

Available online

May 282013

Keywords:

Motivation factors

Management performance

Factorial analysis

\begin{abstract}
A B S T R A C T
Management is often considered as collaboration with others and this requires knowing about employers' behavior and the factors influencing their behaviors to motivate them for obtaining some predicted aims. This paper presents a study to detect important factors influencing motivation of some employees who work for a public offices in city of Kashan, Iran. The study designs a questionnaire in Likert scale and distributes it among 160 randomly selected participants. The questions are divided into two groups of management performance and motivational factors. To evaluate the effect of demographic factors on the quality of respondents' statements, a rating analysis based on Kruskal-Wallis test is used. To measure the effective vote, the motivation levels are divided into three groups of highly motivated, motivated and not motivated and they are analyzed based on rating mean variance with freedman scale. The results indicate that interesting job, job security, good salary and benefits and promotions, etc. are important factors to impact on the employers' motivation. For the newly - employed personal, job security is the most important motivation factor and for old established employees, job attractive and sense of being considered is the most effective factor.
\end{abstract}

(C) 2013 Growing Science Ltd. All rights reserved.

\section{Introduction}

Management is often considered as collaboration with others and this requires knowing about employers' behavior and the factors influencing their behaviors to motivate them for obtaining some predicted aims. There are many evidences to believe that many human resources only use a small amount of their work experiences to contribute to their work. In some public offices such as municipalities and other offices, permanent workers are less motivated and in some cases, they do not have good motivation to contribute to their working environment (Chyung, 2001). There are cases where human resources work only for a few minutes in their office. Schwab et al. (1971) conducted some researches on the relationship between job satisfaction and performance. They selected a sample including 124 employees of accounting and management department and reported that there was no distinguishable performance originated from motivational and environment factors. Ewen et al. (1966) selected 800 male employees from various jobs and found that using Herzberg discussions *Corresponding author. Tel: +982182884674 
related to the root was doubtful, and other studies gave no sufficient document to approve two factor theory. Green (1966) confirmed Aven's studies and confirmed his work in classic categorizing of the job satisfaction factors into internal and external motivations factors. Haus and Vigdour (1976) examined the two-factor theory and criticisms and criticized Herzberg's primary's studies and for several reasons such as methodology and lack of considering past experiences. Far (1977) examined the two-factor theory in association with the new existing method in psychology. In Far's view, Herzberg presented a reliable view on individuals' feelings about their daily working environment; but he made some false conclusion. Burner et al. (1971) selected 500 accountants in US and found that environmental and motivational factors both were effective on job satisfaction or disseat is factions. Maidan (1991) examined the two-factor theory by distributing questionnaire among the personnel of private and public sectors. His finding showed that motivational factors are moving effective on job satisfaction.

Taber (1991) used professional researches to test job satisfaction among the telephone operators. They found the same result, which was originally detected by Herzberg. Pennings (1970) showed that the two-factor theory is right for all employee and system value but sometimes the employees' and systems value could be different. Kaat and kondly (2009) examined the Herzberg-theory for evaluating the motivation factors among the students and found that some new founding, shall be introduced for define all reactions and responds. Wood and Lebold (1970) found that job satisfaction was multi delusional and the two-factor theory was a simple definition for a complex system of feeling, and reactions. Shiply and killy (1986) found that the two-factor theory is a good start point for managers, but it may not be recommended, for its simplicity, in complex cases. Some researchers in Uganda found that every factor could create motivation or dissatisfaction depending on situational variables.

Schrooder (2008) used the two-factor theory as a theoretical framework to conduct study on 835 universities: employees. He aimed at examining the effect of human factors on job satisfaction. His findings were the opposite of Herzberg's findings, because he wanted to examine the effect of human factors on job satisfaction. His finding were in contrary to Herzberg's findings, because he found that job satisfaction was depended on age and education level and internal and external satisfactions were the same for different working groups. Surviving is the only need of masons; they have no dream of flourishing their personality, and cannot understand the motivational factors.

Herzberg presented different embays on confirming and approving his main essay about the twofactor theory. He is believed to be the first who conducted the first experimental research, on job satisfaction in Soviet Union where he performed a survey on 2665 workers of various heavy and light industries. Researchers found that the most effective and important factor influencing good performance was satisfaction with that job (Herzberg, 1965). This result is exactly associated with Herzberg definition of every one's job as a motivational factor. Semerek and Peterson (2007) believed that Herzberg's two - factor theory was the one, which stands against time and it can be included in the main theories and can present some new ideas for modern generation.

Behling et al. (1968) found that the discussions about this theory went to some terms as "I am right and you are wrong" and this caused the theory not to be improved. They explained that those researches conducted after Herzberg disunions, generally confirmed the two-factor theory, and those researches using other theories, and did not confirm this theory. Schwab and Henman (1970) used Herzberg's methods to examine some objections to the two-factor theory, but they found that they could not exactly forecast certain response and reactions to pleasant and unpleasant successions.

According to Herzberg (1965), there are some differences between careful management (KITA) and management through motivation. In 1971, in an interview he proceeded to practical uses of the two factor theory. According to Herzberg (1979), it is not possible to completely enrich every job and work. 
According to Hugo (1985), Enrichment can lead to job satisfaction only when job's financial affairs become problematic. Others also agree with this idea and emphasize on the relative importance of workers' preparing for enrichment through management support and good training. Ford (1969) reviewed the effects of enrichment as a method of improving job satisfaction. He believed that, when we change a job we not only consider the impact of the change on customers, costs and products but also the effect of relationship among employees. Davin and Allen (1970) investigated the time length of feeling and emotions made by some employees who had implemented Herzberg factors. They found that many emotions were longer than little emotions. Esteed (1972) considered two factor theory of Herzberg to Barlow's relation model and found that this kind of use of the two - factor theory would cause some defects in relations.

Atchison and Lefferts (1972) conducted some studies for escort employees' transfer by using Herzberg's job satisfaction technique and reported that Herzberg's theory was not clear and defined as the theory shows. Spillan (1973) reported no difference between those who remained in their job and these who left their job based on job satisfaction. Lahif (1976) showed a great difference between the scares of reading of unity and proved that a great degree of unity feeling was found in motivational factors. According to Semirek and Peterson (2007) "Research and theory do not mean you want to give value to that theory". Chaung (2001) studied the masons in Bangkok and their results did not confirm the two-factor theory, but they thought that the obtained results might be in Maslow's hierarchy of needs due to the lower position of means. Ondrak (1974) performed another investigation on Herzberg's findings and his results did not confirm Herzberg's results but disclosed some new insights. He reported that motivational and environmental - external factors influence job satisfaction and dissatisfaction. Knoop (1994) studied Herzberg's factors to job values and revealed that internal factor could have inverse relationship with stress. Toten and August (1998) investigated customer's response and considered two factor theory by referring to their satisfaction and dissatisfy faction with service companies. Tamosaitis and schwenker (2002) showed that external factors had important effects on employees' transfer and job, by itself, and it could create job satisfaction and external factors may be treated as a fetor of keeping the employees. Rogers (2005) performed an investigation in educational institutes and showed that those employees who were not satisfied with their jobs retired from their jobs' subsidiary affairs and could not set long-term aims. Sachwa (2007) collaborated with Herzberg and considered the progress history of this theory. Samuel and Chipunza (2009) researched an internal and external motivational variables, influencing the employees' retain and decrease of their transfer. Halowell (2005) showed that when employee do repeated works they may lose their motivation and productivity decreases. Nickson (2003) recommended that managers could provide an environment to motivate their employees. Those managers who have a right understanding of their employees' needs and wishes can do that. They are those managers who engage their employees in company affairs. According to Buckingham (2005), knowing the employees' competences can create a good environment for employees to work better and better concentration on their learning.

\section{Research Hypotheses}

Hypothesis $1(\mathrm{p} 1)$ : There is a significant difference, based on education level, between motivated, highly motivated and not motivated employees in terms of the level of interest in job, good salary, appreciation for good work, job security, good work conditions promotion, feeling of being in on things, loyalty to employees, sympathy with employees personal problems.

Hypothesis 2 (P2): Generally there is no significant difference, based on motivational factors, between motivated, high motivated and not motivated employees in terms of comparing with interesting job, good salary, appreciation for good work, job security, good work conditions promotion, feeling of being in on things, loyalty to employees, sympathy with employees personal problems. 
Hypothesis 3 (P3): There is no significant difference in motivation between men and women in terms of interest in job, good salary, appreciation for good work, job security, good work conditions promotion, feeling of being in on things, loyalty to employees, sympathy with employees personal problems.

Hypothesis 4 (P4): There is no significant difference in motivation between employees with different records at service in terms of interest in job, good salary, appreciation for good work, job security, good work conditions promotion, feeling of being in on things, loyalty to employees, sympathy with employees personal problems.

Hypothesis 5 (P5): There is no significant difference in motivation between employees with different level of training in terms of interest in job, good salary, appreciation for good work, job security, good work conditions promotion, feeling of being in on things, loyalty to employees, and sympathy with employee's personal problems.

\section{Research Methodology}

The proposed model of this study is practical due to relying on the existing theories for with reviewing organizations' problems and due to the use of random sample in inductive reasoning.

\subsection{Statistical sample and community}

Statistical community includes all of Kashan and suburbs public offices employees, which include 10000 people employed in various offices of governmental organizations. We selected 151 people were selected randomly by Cochran formula.

\subsection{Data Analysis Method}

1) Descriptive method: We used mean, standard deviation.

2) Correlation test: We used for measure the Reliability, Bar chart and pie chart for data description of tools and to evaluate the effect of demographic variables (age and term service) on individuals' statement.

3) Normality test: it was used evaluation the normality of quantity variables ' distribution.

4) Variance analysis: It was used for evaluation of the responders' sex effect on their statements.

5) Mean test: It used of evaluation of the respondents' agreement significance based on with degree of affecting mean.

\subsection{Research Model}

The proposed study uses a linear regression function where the dependent variable is the level of motivation and independent variables include, $X_{1}$ to $X_{10}$ are interesting job, good salary, appreciation for good work, job security, suitable working condition, organizational promotion, feeling of being in on things; employee personal loyalty, sympathy with employees personal problems, etc.

$\mathrm{y}=\mathrm{F}\left(\mathrm{x}_{1}, \mathrm{x}_{2} \ldots \mathrm{x}_{10}\right)$

\section{Research Findings}

This research has been conducted based on the returned questionnaires for findings analysis. From 140 returned questionnaires it is near to 70 of people are men and the remaining are women, $56 \%$ married and 40\% single and the remaining were divorced. From sample, 40\% had diploma, 35\% Real Bachelor degree or higher level. 


\subsection{Factor analysis}

All of 53 factors that were used in this research, were first divided into 3 groups, but as the valuations about these 3 groups of 8 factors were not acceptable. Therefore, we divided then into 2 groups; management performance and motivational factors, which were evaluated in significance level of more than 0.001 in Table 1.

\section{Table 1}

The Results of Factorial Analysis

\begin{tabular}{|c|c|c|}
\hline Description of Factor & $\begin{array}{l}\text { Management } \\
\text { Performance }\end{array}$ & $\begin{array}{l}\text { Motivational } \\
\text { Factors }\end{array}$ \\
\hline Job performance being fairly evaluated & 0.530 & 0.000 \\
\hline Receiving recognition for accomplishment & 0.549 & 0.000 \\
\hline Contribution made to company's goals and strategies & 0.531 & 0.000 \\
\hline Motivation to see the company's success & 0.786 & 0.000 \\
\hline Committed to the changes made in the company & 0.592 & 0.000 \\
\hline Communicate goals and strategies & 0.714 & 0.000 \\
\hline Having authority in decision making & 0.583 & 0.000 \\
\hline Involvement in decision making & 0.763 & 0.000 \\
\hline Motivated to be creative & 0.735 & 0.000 \\
\hline Satisfaction with the empowerment given at work & 0.616 & 0.000 \\
\hline Money being the only motivator & 0.844 & 0.000 \\
\hline Feeling of making a difference at work & 0.503 & 0.000 \\
\hline Positive changes leadership has made & 0.729 & 0.000 \\
\hline Referring family or friends to work at the company & 0.611 & 0.000 \\
\hline Satisfaction with the team spirit at work & 0.547 & 0.000 \\
\hline Feeling of a sense of accomplishment & 0.544 & 0.000 \\
\hline Enjoyable working environment & 0.606 & 0.000 \\
\hline Understanding of company's mission & 0.650 & 0.000 \\
\hline Feedback given to improve performance & 0.000 & 0.670 \\
\hline Respect and flexibility towards family responsibility & 0.000 & 0.569 \\
\hline Mistakes acceptable in the process of trying new things & 0.000 & 0.575 \\
\hline $\begin{array}{l}\text { Satisfaction with the supervisor as a role } \\
\text { Model }\end{array}$ & 0.000 & 0.699 \\
\hline Receiving coaching and training & 0.000 & 0.552 \\
\hline Have enough training to perform the tasks required & 0.000 & 0.418 \\
\hline Opportunities to interact with other employees & 0.000 & 0.454 \\
\hline Availability for consolation from the supervisor & 0.000 & 0.739 \\
\hline Promotions & 0.000 & 0.847 \\
\hline Training when necessary & 0.000 & 0.709 \\
\hline Supervisor listen and meet the employees & 0.000 & 0.910 \\
\hline Supervisor concerned about the employees' needs and problems & 0.000 & 0.798 \\
\hline Company holds social events & 0.000 & 0.515 \\
\hline Supervisor accept comments & 0.000 & 0.879 \\
\hline Supervisors remember personal things & 0.000 & 0.641 \\
\hline Company supports celebration and team building activities & 0.000 & 0.447 \\
\hline Supervisor cares for the employee as an individual & 0.000 & 0.874 \\
\hline Cronbach's Alpha & 0.9364 & 0.9439 \\
\hline$\%$ Variance explained & $51.48 \%$ & $6.37 \%$ \\
\hline Eigen Value & 16.26 & 2.72 \\
\hline
\end{tabular}




\subsection{Determining the results' reliability}

1) Cornbach's Alpha for factors 1: management performance 0.9364; for motivational factors is 0.9356 .

2) Correlation between the two factors: management performance and motivational factors, is 0.663 .

3) Significance level of both factors is more than 0.001 , which shows the generalizability of results.

\subsection{Evaluation of difference between the factors importance}

The result that obtained by Mann Whitney test was used for evaluation of significant differences between the two factors: motivational and management showed in Table 2.

Table 2

Mann Whitney Test: Management practice

\begin{tabular}{|c|c|c|c|c|c|c|c|}
\hline \multirow[b]{2}{*}{ Variables } & \multicolumn{2}{|c|}{ Highly motivated } & \multicolumn{2}{|c|}{ Motivated } & \multicolumn{2}{|c|}{ Not motivated } & \multirow{2}{*}{$\begin{array}{l}\text { Mann } \\
\text { Whitney } \\
\text { Test }\end{array}$} \\
\hline & Mean & $\begin{array}{l}\text { Std. } \\
\text { Dev. }\end{array}$ & Mean & $\begin{array}{l}\text { Std. } \\
\text { Dev. }\end{array}$ & Mean & $\begin{array}{l}\text { Std. } \\
\text { Dev. }\end{array}$ & \\
\hline Interesting work & $3.29 *$ & 0.70 & $3.54 *$ & 0.61 & $3.91 * *$ & 0.71 & $0.0001 * * *$ \\
\hline Good wages & $3.23 *$ & 0.57 & $4.01 * *$ & 0.46 & $3.83 * *$ & 0.94 & $<0.0001^{* * *}$ \\
\hline Appreciation for job well done & $3.03 *$ & 0.63 & $3.76^{* *}$ & 0.58 & $4.02 * *$ & 0.58 & $<.0001 * * *$ \\
\hline Job security & $3.27 *$ & 0.80 & $3.65^{*}$ & 0.64 & $3.92 *$ & 0.67 & 0.1221 \\
\hline Good Working conditions & $3.28 *$ & 0.65 & $3.57 *$ & 0.59 & $3.96 * *$ & 0.77 & $0.0001 * * *$ \\
\hline Promotions and growth in the company & $3.06^{*}$ & 0.58 & $3.84 * *$ & 0.48 & $3.99 * *$ & 0.72 & $<0.0001 * * *$ \\
\hline Feeling of being in on things & $2.96^{*}$ & 0.49 & $3.77 * *$ & 0.60 & $4.12 * *$ & 0.54 & $<0.0001 * * *$ \\
\hline Personal loyalty to employees & $2.81 *$ & 0.64 & $3.79 * *$ & 0.51 & $4.11 * *$ & 0.55 & $<0.0001 * * *$ \\
\hline Tactful discipline & $2.99 *$ & 0.90 & $3.71 * *$ & 0.53 & $4.20 * *$ & 0.56 & $<0.0001 * * *$ \\
\hline Sympathetic help with personal problems & $3.02 *$ & 0.86 & $3.69 *$ & 0.56 & $4.13 * *$ & 0.47 & $0.0001 * * *$ \\
\hline
\end{tabular}

Table 2 shows the mean difference between various motivational levels in which motivational levels are divided into 3 levels. High motivated, motivated and not motivated. The means difference of motivational factors for independent variable of management performance for all the above factors were accepted in confidence level of $99 \%$ except for job security which was accepted in 0.95 levels. Similarly this test has been used in evaluating the difference between the effects of motivational factors outlined in Table 3.

Table 3

Mann Whitney Test: motivation factors

\begin{tabular}{|c|c|c|c|c|c|c|c|}
\hline \multirow[b]{2}{*}{ Variables } & \multicolumn{2}{|c|}{ Highly motivated } & \multicolumn{2}{|c|}{ Motivated } & \multicolumn{2}{|c|}{ Not motivated } & \multirow{2}{*}{$\begin{array}{l}\text { Mann } \\
\text { Whitney } \\
\text { Test }\end{array}$} \\
\hline & Mean & $\begin{array}{l}\text { Std. } \\
\text { Dev. }\end{array}$ & Mean & $\begin{array}{l}\text { Std. } \\
\text { Dev. }\end{array}$ & Mean & $\begin{array}{l}\text { Std. } \\
\text { Dev. }\end{array}$ & \\
\hline Interesting work & $2.90 * *$ & 0.82 & $3.21 *$ & 0.50 & $3.24 *$ & 0.77 & 0.0406 \\
\hline Good wages & $2.97 *$ & 0.65 & $3.39 * *$ & 0.55 & $3.18 * *$ & 0.82 & 000012 \\
\hline Appreciation for job well done & $2.71 *$ & 0.69 & $3.28 * *$ & 0.52 & $3.43 * *$ & 0.67 & $<0.0001 * * *$ \\
\hline Job security & $2.86^{*}$ & 0.69 & $3.16^{*}$ & 0.58 & $3.41 * *$ & 0.71 & 0.0214 \\
\hline Good Working conditions & $2.43 *$ & 0.95 & $3.21 * *$ & 0.53 & $3.30 * *$ & 0.76 & 0.0139 \\
\hline Promotions and growth in the company & $2.84 *$ & 0.72 & $3.30 * *$ & 0.54 & $3.39 * *$ & 0.66 & $<0.0001 * * *$ \\
\hline Feeling of being in on things & $2.82 *$ & 0.67 & $3.21 * *$ & 0.64 & $3.52 * *$ & 0.52 & $<0.0001 * * *$ \\
\hline Personal loyalty to employees & $2.59 *$ & 0.87 & $3.28 * *$ & 0.49 & $3.49 * *$ & 0.58 & $<0.0001 * * *$ \\
\hline Tactful discipline & $2.96^{*}$ & 0.78 & $3.18^{*}$ & 0.58 & $3.52 * *$ & 0.72 & 0.0028 \\
\hline Sympathetic help with personal problems & $2.72 *$ & 0.79 & $3.17 *$ & 0.57 & $3.65 * *$ & 0.46 & $0.0001 * * *$ \\
\hline
\end{tabular}

Table 3 shows the comparison of means between 3 groups of people with 3 levels of motivation (highly motivated, motivated and not motivated). Mean-difference of motivational factors (appreciation for good work, promotions, feeling of being in on things, loyalty to employees and 
sympathy and help in personal problems is meaningful at $99 \%$ confidence level and for interesting job, good salary, job security, good working conditions and tactful discipline is meaningful at confidence level of $95 \%$.

\subsection{Analysis of statements correspondence}

Evaluation of the effect of personality factors or demographic variables on the way of respondents' statement has been conducted by using variance analysis in chi square value.

\section{Table 4}

Chi square test for Gender as independent variable

\begin{tabular}{lcccc}
\hline \multirow{2}{*}{ Variables } & \multicolumn{2}{c}{ Frequency } & \multirow{2}{*}{ Chi-Square } & \multirow{2}{*}{ P-value } \\
\cline { 2 - 3 } & Male & Female & & \\
\hline Interesting work & 114 & 22 & 0.8375 & 0.6579 \\
Good wages & 114 & 23 & 5.8412 & $0.0539^{* * *}$ \\
Appreciation for job well done & 112 & 23 & 0.0894 & 0.1294 \\
Job security & 114 & 23 & 1.2894 & 0.5248 \\
Good working conditions & 112 & 23 & 2.0130 & 0.3655 \\
Promotions and growth in the company & 114 & 23 & 1.0844 & 0.5815 \\
Feeling of being in on things & 114 & 23 & 0.4142 & 0.8129 \\
Personal loyalty to employees & 114 & 23 & 0.7266 & 0.6954 \\
Tactful discipline & 112 & 23 & 1.1502 & 0.5626 \\
Sympathetic help with personal problems & 114 & 23 & 5.2032 & $0.0742^{* * *}$ \\
\hline P*** statistically significant difference & & & &
\end{tabular}

Table 4 shows a significant difference between employees' statements according to their gender and based on the following motivational factors,

Good salary; and sympathy with personal problems. In addition, our results show that women are motivated by good salary better than the men are. Even if there is some difference between their genders but they are not significant. The results of statements correspondence analysis with years working are shown in Table 5.

Table 5

Chi-square test for the Years working variable

\begin{tabular}{|c|c|c|c|c|}
\hline \multirow[b]{2}{*}{ Variables } & \multicolumn{2}{|c|}{ Frequency } & \multirow[b]{2}{*}{ Chi-Square } & \multirow[b]{2}{*}{ P-value } \\
\hline & $\begin{array}{c}0-5 \\
\text { years }\end{array}$ & $\begin{array}{c}6+ \\
\text { years }\end{array}$ & & \\
\hline Interesting work & 59 & 78 & 7.5864 & $0.0225 * * *$ \\
\hline Good wages & 59 & 79 & 2.3400 & 0.3104 \\
\hline Appreciation for job well done & 59 & 77 & 2.5032 & 0.2860 \\
\hline Job security & 59 & 79 & 2.5270 & 0.2827 \\
\hline Good working conditions & 57 & 79 & 0.1148 & 0.9442 \\
\hline Promotions and growth in the company & 59 & 79 & 2.6711 & 0.2630 \\
\hline Feeling of being in on things & 59 & 79 & 3.9186 & 0.1410 \\
\hline Personal loyalty to employees & 59 & 79 & 0.1568 & 0.9246 \\
\hline Tactful discipline & 57 & 79 & 1.1309 & 0.5681 \\
\hline Sympathetic help with personal problems & 59 & 79 & 2.5194 & 0.2837 \\
\hline
\end{tabular}

$\alpha<0.05$ (95\% confidence level)

$\alpha<0.001$ (99\% confidence level)

Based on the results of Table 5, we see that interesting job is the only factor that shows a significant difference at level of lower than 0.05. In the scope of these employees who have worked for more than 6 years, interesting job is treated more important compared with the employees who have 
worked for less than 5 years. The results of the analysis of statements correspondence for the effect of education level on motivational factors are summarized on Table 6.

\section{Table 6}

Chi-square test for Education level as the independent variable

\begin{tabular}{|c|c|c|c|c|}
\hline \multirow[b]{2}{*}{ Factors } & \multicolumn{2}{|c|}{ Frequency } & \multicolumn{2}{|l|}{ Chi - } \\
\hline & $\begin{array}{c}0-5 \\
\text { years }\end{array}$ & $\begin{array}{c}6+ \\
\text { years }\end{array}$ & $\begin{array}{c}\text { Square } \\
\text { value }\end{array}$ & Sig. \\
\hline Interesting work & 58 & 77 & 3.8122 & 0.1487 \\
\hline Good wages & 58 & 78 & 0.2271 & 0.8926 \\
\hline Appreciation for job well done & 58 & 77 & 1.4097 & 0.4942 \\
\hline Job security & 58 & 78 & 7.0786 & $0.0290 * * *$ \\
\hline Good working conditions & 57 & 77 & 3.8944 & 0.1427 \\
\hline Promotions and growth in the company & 58 & 78 & 6.6666 & $0.357 * * *$ \\
\hline Feeling of being in on things & 58 & 78 & 0.9237 & 0.6301 \\
\hline Personal loyalty to employees & 58 & 78 & 0.3500 & 0.8395 \\
\hline Tactful discipline & 58 & 76 & 3.8716 & 0.1443 \\
\hline Sympathetic help with personal problems & 58 & 78 & 6.0381 & $0.0188 * * *$ \\
\hline
\end{tabular}

With regard to education level, the employees with Bachelor science or higher degrees have treated the discussed variables more important than others have.

\section{Conclusion}

The results of this survey have shown that there was a direct relationship between management performance and employees' motivation. Based on the results, the correlation coefficient between management performance and motivational factors was calculated as 0.663 , which shows a direct and strong relationship between these two variables. Based on Mann Whitney test, in which management performance is an independent variable, it has been shown that some factors including interesting job with good salary, appreciation for good working, good working conditions, felling of being in on the things, organizational loyalty, tactful discipline and half and sympathy with employees are statistically significant with $\alpha=0.01$. In the second Mann Whitney test, it has been shown that some factors such as: appreciation for good work, promotions and sympathetic help to employees are statistically significance with $\alpha=0.01$. Furthermore, the results have showed that motivation factors including interesting job, job security, good working conditions and tactful discipline were statically significant with $\alpha=0.01$.

Analysis of statements correspondence by Chi-square test based on demographic variables or personality features of respondents including gender, years of service, level of education, in relation to management performance including: interesting work good salary, appreciation for good working; job security; promotions, feeling of being in on things; personal loyalty to employees; tact feel discipline and sympathetic help with personal problems show the following result:

1) There was a significant difference, in terms of the effect of motivation by good salary and sympathetic help with personal problems, between men and women employees.

2) Employees with more than 6 years of service treated interesting job more important than others did. They may have enough job security, receive good salary and appreciation by their managers and they were satisfied with their working conditions.

3) Employees having university educations treated motivational factors including job security, promotions, and sympathetic help with personal problems more important than employees with lower education levels did. 


\section{References}

Atchison, T.J. \& Lefferts, E.A. (1972). The predication of turnover using Herzberg's job satisfaction technique. Personnel Psychology, 25(1), 53-64.

Behling, O., Labovitz. G., \& Kosmo, R. (1968). The Herzberg Controversy: A Critical Reappraisal. Academy of Management Journal, 11(1), 99-108.

Brenner, V., Carmack, C., \& Weinstein, M. (1971). An empirical test of the motivation-hygiene theory. Journal of Accounting Research, 9(2), 359-366.

Buckingham, M. (2005). What Great Manager so. Harvard Business Review, 3(3), 70-79.

Chyung, S.Y. (2001). Systemic effects of improving the motivation appeal of online instruction on adult distance. Education $A$ paper presented at the $82^{\text {nd }}$ annual conference of the American Educational Research Association (AERA) in Seattle, W A.

Davin, K. \& Allen, G. (1970). Length of Time that Feelings Persist for Herzberg's Motivational and Maintenance Factors. Personnel Psychology, 23(1), 67-76.

Even, R., Smith, P., Hulin, C, \& Locke, E. (1966). An empirical test of the Herzberg two-factor theory. Journal of Applied Psychology, 50(6), 544-550.

Farr, R. M. (1977). On the nature of attributional artifacts in qualitative research: Herzberg's twofactor theory of work motivation. Journal of Occupational Psychology, 50(1), 3-14.

Ford, R. (1969). The obstinate employee. The Public Opinion Quarterly, 33(3), 301-310

Graen, G. (1966). Addendum to "An empirical test of the herzberg two-factor theory". Journal of Applied Psychology, 50(6) 551-555.

Hague, D. J. (1985). Incentives and motivation in the construction industry: A critique. Construction Management and Economics, 3(2), 163-170.

House, R. \& Wigdor, L. (1976). Herzberg's dual-factor theory of job satisfaction and motivation: A Review of the Evidence and Criticism. Personnel Psychology, 20(4), 369-389.

Herzberg, F. (1965). The motivation to work among Finnish supervisors. Personnel Psychology, 18(4), 393-402.

Herzberg, F. (1979). Motivation and Innovation: Who are Workers serving?. California Management Review, 22(2), 60-70.

Hallowel, E.M. (2005). Overloaded circuits: Why smart people underperfrom. Harvard Business Review, 83, 54-62.

Katt, J. \& Condly, S. (2009). A preliminary study of classroom motivators and de-motivators from a motivation-Hygiene perspective. Communication Education, 58(2), 213-234.

Knoop, R. (1994). Reliving stress through value-Rich Work. The Journal of Social Psychology, 134(6), 829-836.

Lahiff, J. (1976). Motivators, hygiene factors, and empathic communication. Journal of Business Communication, 13(3), 15-23.

Maidani, E. (1991). Comparative study of Herzberg's two-factor theory of job satisfaction among public and private sectors. Public Personnel Management, 20(4), 441-448.

Samuel, M. O., \& Chipunza, C. (2009). Employee retention and turnover: Using motivational variables as a panacea. African Journal of Business Management,3(8), 410-415.

Nicholson, N. (2003). How to motivate your problem people. Harvard Business Review, 81(1), 5765 .

Ondrak, D.A. (1974). Defense mechanisms and the Herzberg theory: An alternate test. Academy of Management Journal, 17(1), 79-89.

Pinning's, J. (1970). Work-value systems of white-collar workers. Administrative Science Quarterly, 15(4), 397-405.

Rogers, J. (2005). Aspiring to leadership-identifying teacher-leaders. Medical Teacher, 27(7), 629633.

Sachau, D. (2007). Resurrecting the motivation-hygiene theory: Herzberg and the positive psychology movement. Human Resource Development Review, 6(4), 377-393. 
Dunbar, S. B. (2003). Perceived motivational factors among allied health managers and subordinates. The Internet Journal of Allied Health and Sciences and Practice, 1(1).

Schoroder, R. (2008). Job satisfaction of employees at a Christian university. Journal of Research on Christian Education, 17(2), 225-246.

Schwab, D. \& De Vitt, W. (1971). A test of the adequacy of the two factor theory as a predictor of self-report performance effects. Personnel Psychology, 24(2), 293-303.

Schwab, D. \& Hahnemann, H. (1970). Aggregate and Individual Predictability of the two Factor Theory of Job Satisfaction”. Personnel Psychology, 23(1), 55-66.

Semerek, R. \& Peterson, M. (2007). Examining Herzberg's Theory: Improving job satisfaction among non-academic employees at a University. Research in Higher Education, 48(2), 229-250.

Shipley, D. \& Kiely, J. (1986). Industrial sales force motivation and Herzberg's dual factor theory: A UK perspective. Journal of personal Selling \& Sales Management, 6(1) 9-16.

Spillane, R. (1973). Intrinsic and extrinsic job satisfaction and labour turnover. Occupational Psychology, 47(1/2), 71-74.

Stead, B. (1972). Berol's communication process model as applied to the behavioral theories of Maslow, Herzberg, and McGregor. Academy of Management Journal, 15(3), 389-394.

Taber, T. (1991). Triangulating job attitudes with interpretive and Positivist measurement methods. Personnel Psychology, 44(3), 557-600.

Tuten, T. \& August, R. (1998). Understanding consumer satisfaction in service settings: A bidimensional model of service strategies. Journal of Social Behavior and Personality, 13(3), 553564.

Wood, D. \&. Lebold, W. (1970). The multivariate nature of professional job satisfaction. Personnel Psychology, 23(2), 173-189.

Tamosaitis, W. \& Schwenker, M. (2002). Recruiting and retaining technical personnel at a contractor-operated government site. Engineering Management Journal, 14(1), 29-34. 